\title{
Analysis of Virological, Histological and Clinical Features of Hepatitis Delta Virus Infection in Southeastern Turkey
}

\author{
Güneydoğu Anadolu Bölgesi'ndeki Delta Hepatit Virüs Enfeksiyonlu Hastalarımızın \\ Virolojik, Histolojik ve Klinik Özelliklerinin Analizi
}

\author{
(1) Mehmet Suat YALÇIN, (1) Kendal YALÇIN
}

Dicle University Faculty of Medicine, Department of Internal Medicine, Division of Gastroenterology and Hepatology, Diyarbakır, Turkey

\begin{abstract}
Objectives: The present study aims to investigate biochemical, virological and histological characteristics of hepatitis delta virus infection, which is a serious problem in our region, as well as its relationship with chronic hepatitis $B$ virus (HBV) infection and cirrhosis. Materials and Methods: A total of 220 patients were included in the study. The patients were divided into three groups: group 1 included patients with hepatitis delta virus-related cirrhosis (DA cirrhosis), group 2 consisted of patients with chronic delta hepatitis (CHD) and group 3 composed of patients with chronic hepatitis B (CHB). Biochemical and virological parameters of the patients were analyzed. Patients with $\mathrm{CHB}$ and $\mathrm{CHD}$ underwent biopsy for histological examination. The results were compared among the three groups.

Results: Seventy-five (34.09\%) of the patients were women, 145 $(65.90 \%)$ were males and their mean age was 38.04 years. There were 44 patients (20\%) with delta hepatitis-associated cirrhosis, 86 patients with $\mathrm{CHD}(39.09 \%)$ and 90 patients with CHD (40.9\%). HBV DNA level was significantly lower in patients with cirrhosis and chronic delta hepatitis than in patients with $\mathrm{CHB}(\mathrm{p}<0.001)(p<0.001)$. Histology activity score and fibrosis stage were significantly higher in $\mathrm{CHD}$ than in $\mathrm{CHB}(\mathrm{p}<0.001)(\mathrm{p}<0.001)$. A significant correlation was determined between fibrosis stage and hepatitis delta virus RNA in CHD patients. There was also a significant correlation between necroinflammatory score and alanine aminotransferase in $\mathrm{CHD}(\mathrm{p}=0.021)$.

Conclusion: In Turkey, the age of onset of delta hepatitis is low and accordingly, related liver cirrhosis develops at a younger age. HBV DNA levels appear to be suppressed in patients with delta hepatitis as compared to patients with CHB. Histologically severe disease picture is seen in patients with delta hepatitis and delta hepatitispositive cirrhotic patients.
\end{abstract}

Keywords: Hepatitis delta virus, hepatitis B virus, cirrhosis, liver biopsy
ÖZ

Amaç: Hepatitis delta virüsü replikasyonu için hepatit B yüzey antijenine intiyaç duyan defektif bir virüstür. Bu çalışmadaki amacımız bölgemizdeki delta hepatitli hastaların virolojik, histolojik ve biyokimyasal özelliklerini araştırmaktır.

Gereç ve Yöntemler: Toplam 220 hasta çalışmaya alındı. Hastalar üç grupta incelendi: delta hepatite bağlı siroz (DI siroz), kronik delta hepatit (CHD) ve kronik hepatit B (CHB). Kronik delta ve hepatit B grubundaki hastaların biyopsilerindeki histolojik özellikleri incelendi. Üç grubun özellikleri karşılaştıııldı.

Bulgular: Hastaların $75^{\prime} \mathrm{i}(\% 34,09)$ kadın, $145^{\prime} \mathrm{i}(\% 65,90)$ erkek ve ortalama yaşları 38,04 idi. Delta hepatite bağlı sirozlu 44 hasta (\%20), CHD'li 86 hasta $(\% 39,09)$ ve CHB'li $90(\% 40,9)$ hasta vardı. Siroz ve kronik delta hepatitli gruplar arasında HBV DNA düzeyleri açısından anlamlı farkllık yoktu $(p=0,466)$. Ancak bu iki grubun HBV DNA düzeyleri kronik hepatit B'li gruba göre anlamlı olarak düşüktü $(p<0,001-p<0,001)$. CHD'nin histolojik aktivite ve fibrozis evresi CHB'den anlamlı olarak yüksekti $(p<0,001)(p<0,001)$. CHD'deki hastaların HDV RNA değeri ile fibrozis evreleri arasında anlamlı korelasyon vardı. Bu grupta alaninamino transferaz ile histolojik aktivite arasında anlamlı korelasyon saptandı $(p=0,021)$

Sonuç: Türkiye'de delta hepatit başlangıç yaşı küçük olduğu için kronik karaciğer hastalığı da genç yașta ortaya çıkar. Delta hepatit, delta ile ilişkili siroz ve hepatit B'li hastaların ALT düzeyi farklılıklar gösterir. HBV DNA seviyeleri, delta hepatitli hastalarda kronik hepatit B'li hastalarla karşılaştııılığında baskılanmıştır. Histolojik olarak delta hepatit pozitif hastalarda daha ağır bir hastalık tablosu mevcuttur. Anahtar Kelimeler: Hepatit delta virüs, hepatit B virüs, siroz, karaciğer biyopsisi

Yalçın MS, Yalçın K. Analysis of Virological, Histological and Clinical Features of Hepatitis Delta Virus Infection in Southeastern Turkey. Viral Hepat J. 2018;24:47-52. 


\section{Introduction}

Hepatitis delta virus (HDV) is a defective RNA virus. HDV causes co-infection and super infection by using hepatitis B virus (HBV) surface antigen (HBsAg). Today, HDV infection remains a serious health problem particularly in endemic regions (1). There are more than 240 million chronic carriers of HBV, and approximately 15 million of them have serological evidence of exposure to HDV, worldwide $(2,3,4)$.

The prevalence of HDV infection in Europe has changed with the control of HBV infection achieved in the last 20 years (5). The current prevalence of HDV infection among HBsAg carriers is approximately $10 \%$ in Italy (6) and $11 \%$ in Turkey (7). In Turkey, HDV strains exhibit wide genetic diversity reflecting an ancient evolution and/or successive outbreaks (8). However, HDV still accounts for almost one half of overall cases of liver cirrhosis and hepatocellular carcinoma in southeastern Turkey (9).

Chronic HBV and HDV infections have wide range of clinical manifestations from the state of asymptomatic carrier to chronic active hepatitis, liver cirrhosis and hepatocellular carcinoma. However, underlying mechanisms of such clinical variety have not been fully defined yet (1). In the present study, we aimed to investigate biochemical, virological and histological parameters in HDV infection, which is a serious problem in our region, and to investigate its relationship with HBV and HDV viral loads. Within this context, our aim is to designate characteristic features of HDV and it will contribute to determining the follow-up, treatment and natural course of the disease.

\section{Materials and Methods}

The study included a total of 220 patients [75 (34.09\%) females and $145(65.90 \%)$ males] aged between 15 and 70 years, who were admitted to the gastroenterology and hepatology inpatient or outpatient clinics at Dicle University Faculty of Medicine Gastroenterology and Hepatology Department and fulfilled the inclusion criteria. Physical examination findings, results of laboratory tests for biochemical, hematological and virological parameters and HBV and HDV markers, and epidemiologic history of all patients were recorded.

\section{Study Groups and Definition}

Patients were grouped into three groups:

HDV-related cirrhosis (DA cirrhosis).

Chronic hepatitis delta (CHD) without cirrhosis.

Chronic hepatitis B (CHB) (without hepatitis D).

HBsAg-positive and anti-HBs-negative patients, who had undulating alanine aminotransferase (ALT) concentrations for at least 6 months were defined as CHB patients. Liver biopsy was performed in 45 patients in $\mathrm{CHD}$ and in 77 patients in CHB. Histopathological findings were recorded.

The present study was retrospective.

\section{Eligibility Criteria}

Treatment-naive patients or patients who did not receive treatment for at least six months were included in the study.

The diagnosis of liver cirrhosis was established based on laboratory, histological analysis or abdominal ultrasonography findings which demonstrated hepatic surface irregularity, caudate lobe hypertrophy, splenomegaly and injury to the hepatic parenchyma, and on the presence of esophageal varices confirmed by endoscopy. The group with active CHD consisted of patients with positive HBsAg and anti-delta antibody and negative antiHBs for at least six months, with ALT/aspartate aminotransferase (AST) levels higher than 1.5 times the upper limit of normal, and moderate-to-severe active hepatitis shown by liver biopsy.

\section{Exclusion Criteria}

Patients with an accompanying infection with hepatitis $C$ virus $(\mathrm{HCV})$, non-hepatotropic viruses such as human immunodeficiency virus, herpes simplex virus, cytomegalovirus and Epstein-Barr virus, patients with heavy alcohol consumption (more than 8 drinks per week), those using drugs (that may induce hepatitis) and herbal medicines, and patients having autoimmune hepatitis, hepatic ischemia and pregnancy-related liver disease were excluded from the study.

\section{Biochemical and Hematological Markers}

Biochemical [albumin, globulin, lactic dehydrogenase, total bilirubin, ALT, AST, creatinine, glucose, alkalen phosphatase (ALP), gama glutamyltranspeptidase and alpha-fetoprotein (AFP)] and hematological (ferritin, serum iron, serum iron binding capacity, leukocyte, hemoglobin, platelet, and prothrombin time) parameters were analyzed in all patients. Biochemical parameters were analyzed using an Architect C16000 device and complete blood count was analyzed using an Abbott CELL-DYN 3700 device.

\section{Serological and Virological Testing}

The serological markers of HBsAg, anti-HBs, hepatitis B e $(\mathrm{HBe})$ antigen and anti-HBe were tested by macro-ELISA method, whereas anti-delta immunoglobulin (lg) $\mathrm{M}$ and anti-delta IgG were tested by micro-ELISA method. HDV RNA level was analyzed by real time reverse transcriptase polymerase chain reaction (PCR) (ABI-PRISM/7700 Sequence Detector, AJ RoboscreenGmBH, Germany) method, whereas HBV DNA was analyzed by COBAS Ampli Prep/CobasTaq Man HBV test (ROCHE, USA).

\section{Liver Biopsy}

Liver biopsy was planned for histological examination in patients with $\mathrm{CHB}$ and $\mathrm{CHD}$. Fine needle biopsy was performed using the Menghini technique under the guidance of ultrasonography. All biopsies were stained with hematoxylin-eosin for grading necroinflammation and reticulin for the assessment of fibrosis. Biopsy materials were blindly evaluated by a single pathologist. Histologic scoring was done using the Ishak-modified histology activity index (10). Fibrosis was assessed according to Ishak fibrosis score. The Ishak system has more stages of fibrosis (0-6) when compared to other systems (11). Because of having the ability to differentiate milder changes in fibrosis more clearly, the Ishak staging system has been widely used in clinical trials (12).

\section{Statistical Analysis}

Statistical analysis was done by 'SPSS 16.0 for Windows' package program. The results were presented as mean \pm standard deviation. Pearson's or Spearman's correlation coefficient was used to analyze correlations. A $p$ value of less than 0.05 was considered statistically significant. 


\section{Results}

\section{Clinical and Demographic Data (Table 1)}

A total of 220 patients with a mean age of 38.04 years, of whom $75(34.09 \%)$ were female and $145(65.90 \%)$ were male, participated in the study. In patients with DA cirrhosis; $16(36.36 \%)$ of 44 patients were female and $28(63.64 \%)$ were male with a mean age of $44.37 \pm 12.42$ years. In patients with CHD; 31 (36.04\%) of 86 patients were female and 55 (63.96\%) were male with a mean age of 37.92 years. In patients with $\mathrm{CHB} ; 28(31.1 \%)$ of 90 patients were female and 62 (68.9\%) were male with a mean age of 35.06 years. Demographic, biochemical and serological characteristics of these groups are shown in Table 1.

The mean age of the patients in DA cirrhosis was significantly higher than in $\mathrm{CHD}(\mathrm{p}=0.006)$ and $\mathrm{CHB}(\mathrm{p}<0.001)$.

\section{Biochemical and Hematological Data}

Analysis of biochemical and hematological data are shown in Table 1. ALP levels in DA cirrhosis were significantly higher than in
CHB $(p<0.001)$. ALP levels in CHD were significantly higher than in CHB $(p=0.001)$. Serum albumin levels in DA cirrhosis patients were significantly lower than in $\mathrm{CHD}$ and $\mathrm{CHB}$ patients. Globulin levels in $\mathrm{DA}$ cirrhosis were significantly higher than in $\mathrm{CHD}(\mathrm{p}<0.001)$. Globulin levels in DA cirrhosis was also significantly higher than in $\mathrm{CHB}(\mathrm{p}<0.001)$. Ferritin levels in DA cirrhosis were found to be significantly higher than in $\mathrm{CHD}(\mathrm{p}=0.032)$ and $\mathrm{CHB}(\mathrm{p}=0.010)$; whereas, no significant difference was found when $\mathrm{CHD}$ was compared with CHB $(p=0.848)$. AFP levels in DA cirrhosis were significantly higher than in $\mathrm{CHD}(\mathrm{p}=0.029)$ and $\mathrm{CHB}(\mathrm{p}<0.001)$; whereas, no significant difference was found between $\mathrm{CHD}$ and CHB $(p=0.270)$. Distribution of demographic, biochemical, hematological and virological characteristics of study participants among groups are shown in Table 1.

\section{Serological Data}

HBV DNA levels in DA cirrhosis group were significantly lower than in CHB group $(p<0.001)$. HDV RNA levels were found to be $4.35 \pm 1.41\left(\log _{10}\right)$ copies $/ \mathrm{mL}$ in patients with DA cirrhosis and $4.69 \pm 1.63\left(\log _{10}\right) \mathrm{copies} / \mathrm{mL}$ in patients with CHD. No significant

\begin{tabular}{|c|c|c|c|c|c|c|}
\hline Variable & $\begin{array}{l}\begin{array}{l}\text { Group 1: HDV related liver } \\
\text { cirrhosis }(n=44)\end{array} \\
\end{array}$ & $\begin{array}{l}\text { Group 2: Chronic delta } \\
\text { hepatitis }(n=86)\end{array}$ & $\begin{array}{l}\text { Group 3: Chronic } \\
\text { hepatitis B }(n=90)\end{array}$ & $p(1-2)$ & $p(1-3)$ & $\mathrm{p}(2-3)$ \\
\hline Age & $44.37 \pm 12.42$ & $37.92 \pm 12.07$ & $35.06 \pm 9.53$ & 0.006 & $<0.001$ & 0.208 \\
\hline Gender (F/M) & $16 / 28$ & $31 / 55$ & $28 / 62$ & - & - & - \\
\hline ALT (U/L) & $83.64 \pm 62.98$ & $94.83 \pm 100.37$ & $80.57 \pm 60.56$ & 0.725 & 0.976 & 0.456 \\
\hline AST (U/L) & $96.14 \pm 73.90$ & $70.21 \pm 112.61$ & $50.50 \pm 45.29$ & 0.213 & 0.009 & 0.259 \\
\hline ALP (U/L) & $118.00 \pm 54.46$ & $103.12 \pm 47.10$ & $79.51 \pm 25.98$ & 0.134 & $<0.001$ & 0.001 \\
\hline GGT (U/L) & $96.14 \pm 109.50$ & $62.76 \pm 56.79$ & $59.73 \pm 122.13$ & 0.167 & 0.115 & 0.978 \\
\hline Albumin (g/dL) & $3.26 \pm 0.53$ & $4.02 \pm 0.43$ & $4.12 \pm 0.35$ & $<0.001$ & $<0.001$ & 0.321 \\
\hline Globulin (g/dL) & $4.53 \pm 0.92$ & $3.87 \pm 0.78$ & $3.43 \pm 0.48$ & $<0.001$ & $<0.001$ & $<0.001$ \\
\hline T.Bilirubin (mg/dL) & $1.72 \pm 1.34$ & $1.00 \pm 1.55$ & $0.82 \pm 0.55$ & $<0.001$ & $<0.001$ & $<0.001$ \\
\hline Creatinine (mg/dL) & $0.80 \pm 0.20$ & $0.85 \pm 0.19$ & $0.89 \pm 0.19$ & 0.353 & 0.025 & 0.289 \\
\hline Glucose (mg/dL) & $112.11 \pm 46.65$ & $102.22 \pm 38.85$ & $94.83 \pm 23.19$ & 0.286 & 0.022 & 0.348 \\
\hline LDH (U/L) & $251.36 \pm 118.92$ & $209.43 \pm 97.98$ & $206.94 \pm 92.57$ & 0.065 & 0.045 & 0.985 \\
\hline Hemoglobin (g/dL) & $12.54 \pm 2.04$ & $14.32 \pm 1.68$ & $14.74 \pm 1.66$ & $<0.001$ & $<0.001$ & 0.260 \\
\hline Leukocyte $\left(\mathrm{mm}^{3}\right)$ & $4559.09 \pm 2172.68$ & $6221.77 \pm 2108.35$ & $6787.67 \pm 1492.03$ & $<0.001$ & $<0.001$ & 0.119 \\
\hline Platelet $\left(\mathrm{mm}^{3}\right)$ & $87281.82 \pm 40736.11$ & $173096.51 \pm 56620.97$ & $226788.89 \pm 55345.39$ & $<0.001$ & $<0.001$ & $<0.001$ \\
\hline INR & $1.39 \pm 0.23$ & $1.23 \pm 0.96$ & $1.04 \pm 0.14$ & 0.339 & 0.007 & 0.113 \\
\hline Iron $(\mathrm{u} / \mathrm{dL})$ & $90.33 \pm 53.97$ & $101.34 \pm 46.24$ & $103.93 \pm 46.65$ & 0.440 & 0.290 & 0.935 \\
\hline $\operatorname{SIBC}(\mathrm{u} / \mathrm{dL})$ & $227.49 \pm 116.96$ & $252.45 \pm 85.46$ & $228.39 \pm 79.02$ & 0.305 & 0.998 & 0.201 \\
\hline Ferritin (u/dL) & $293.25 \pm 483.88$ & $156.33 \pm 186.00$ & $131.85 \pm 232.99$ & 0.032 & 0.010 & 0.848 \\
\hline AFP & $8.44 \pm 9.48$ & $4.97 \pm 8.17$ & $3.23 \pm 4.12$ & 0.029 & $<0.001$ & 0.270 \\
\hline $\begin{array}{l}\text { HBV DNA } \log _{10} \\
(\mathrm{IU} / \mathrm{mL}) \\
\end{array}$ & $3.42 \pm 1.05$ & $3.84 \pm 1.09$ & $5.31 \pm 1.70$ & 0.466 & $<0.001$ & $<0.001$ \\
\hline HDV RNA Log ${ }_{10}$ (copies/mL) & $4.35 \pm 1.41$ & $4.69 \pm 1.63$ & - & 0.335 & - & - \\
\hline $\begin{array}{l}\text { Necroinflammation score, } \\
\text { grade }\end{array}$ & - & $9.30 \pm 2.89$ & $5.95 \pm 2.82$ & - & - & $<0.001$ \\
\hline Fibrosis stage & - & $3.14 \pm 1.24$ & $1.94 \pm 1.40$ & - & - & $<0.001$ \\
\hline
\end{tabular}


difference was found between these two groups in terms of HDV RNA levels $(p=0.335)$. Virological characteristics of study participants are shown in Table 1.

\section{Histological Data}

Based on the liver biopsy findings of the study participants, the mean histological activity score (necroinflammation), which was calculated according to Ishak's scoring system, was $9.30 \pm 2.89$ in $\mathrm{CHD}$ and $5.95 \pm 2.82$ in $\mathrm{CHB}$. It was significantly higher in $\mathrm{CHD}$ than in $\mathrm{CHB}(\mathrm{p}<0.001)$. Comparing the fibrosis stage between $\mathrm{CHD}$ and $\mathrm{CHB}, \mathrm{CHD}$ patients had higher fibrosis stage than $\mathrm{CHB}$ patients $(p<0.001)$. Histopathological findings of the study participants are shown in Table 1.

\section{Correlation Analysis}

A significant correlation was found between fibrosis stage and HDV RNA levels $(r=0.572, p=0.002$ ) (Figure 1). No significant correlation was found between HDV RNA and ALT and AST levels ( $p=0.743$ and $p=0.347$, respectively).

A significant correlation was found between necroinflammation score and ALT in CHD ( $r=0.350, p=0.021)$. The results of correlation analysis in CHD group are shown in Table 2.

HBV DNA levels were significantly correlated with both ALT $(r=0417, p<0.001)$ (Figure 2) and AST levels $(r=0.344, p=0.001)$ (Figure 3) in CHB group. HBV DNA levels were not correlated with necroinflammation scores $(r=0.139, p=0.237)$ and fibrosis stage $(r=0.141, p=0.231)$ in CHB. ALT levels were significantly correlated with necroinflammation score $(r=0.290, p=0.010)$; however, no significant correlation was found between ALT levels and fibrosis stage $(r=0.191, p=0.096)$. While AST levels were correlated with necroinflammation score $(r=0.385, p=0.001)$; it was not correlated with fibrosis stage $(r=0.193, p=0.092)$. The results of correlation analysis in CHB are shown in Table 3.

\section{Discussion}

HDV is a defective RNA virus and causes infection using HBsAg. There have been a limited number of studies investigating factors playing a role in clinical manifestations and events observed

Table 2. Results of correlation analysis in the patients with chronic hepatitis D

\begin{tabular}{|l|l|l|l|}
\hline \multicolumn{2}{|c|}{} & Log HDV RNA & Log HBV DNA \\
\hline $\begin{array}{l}\text { Spearman's } \\
\text { rho NIA }\end{array}$ & Corr. coefficient & 0.350 & 0.079 \\
& $\mathrm{n}$ & $\mathrm{p}=0.08$ & $\mathrm{p}=0.691$ \\
& $\mathrm{n}$ & 26 & 28 \\
\hline Stage & Corr. coefficient & $0.572(* *)$ & 0.046 \\
& $\mathrm{p}$ & $\mathrm{p}=0.002$ & $\mathrm{p}=0.815$ \\
& $\mathrm{n}$ & 26 & 28 \\
\hline ALT & Corr. coefficient & 0.049 & 0.198 \\
& $\mathrm{p}$ & $\mathrm{p}=0.743$ & $\mathrm{p}=0.168$ \\
& $\mathrm{n}$ & 47 & 50 \\
\hline AST & Corr. coefficient & 0.140 & 0.222 \\
& $\mathrm{p}$ & $\mathrm{p}=0.347$ & $\mathrm{p}=0.121$ \\
& $\mathrm{n}$ & 47 & 50 \\
\hline **Correlation is significant at the level of 0.01 (2-tailed), ${ }^{*}$ Correlation is \\
significant at the level of 0.05 (2-tailed) \\
HBV: Hepatitis B virus, HDV: Hepatitis delta virus, ALT: Alanine aminotransferase, \\
AST: Aspartate aminotransferase, N/A: Not applicable \\
\hline
\end{tabular}

during natural history of the disease in patients with $\mathrm{CHD}$ and the dominant virus in the progression of disease. In the present study, we aimed to investigate clinical, virological and histological characteristics of patients with $\mathrm{CHD}$ and with HDV-positive cirrhosis and to compare with those in patients with $\mathrm{CHB}$.

In their study including $48 \mathrm{HBsAg}$ - and anti HDV-positive patients, Yamashiro et al. (13) reported that the mean age of cirrhotic patients $(65.9 \pm 9.3$ years) was higher than that of asymptomatic patients $(61.8 \pm 16.4$ years) and patients with $\mathrm{CHD}$ $(54.2 \pm 12.0$ years) ( $p<0.05$ and $p<0.05$, respectively). Wu et al. (14) reported in their study including 185 patients that the mean age was $43 \pm 16$ years in patients with $C H D$ and $54 \pm 10$ years in cirrhotic patients. In our study the mean age of patients in DA cirrhosis, $\mathrm{CHD}$ and $\mathrm{CHB}$ was $44.37 \pm 12.42$ years, $37.92 \pm 12.07$ years and

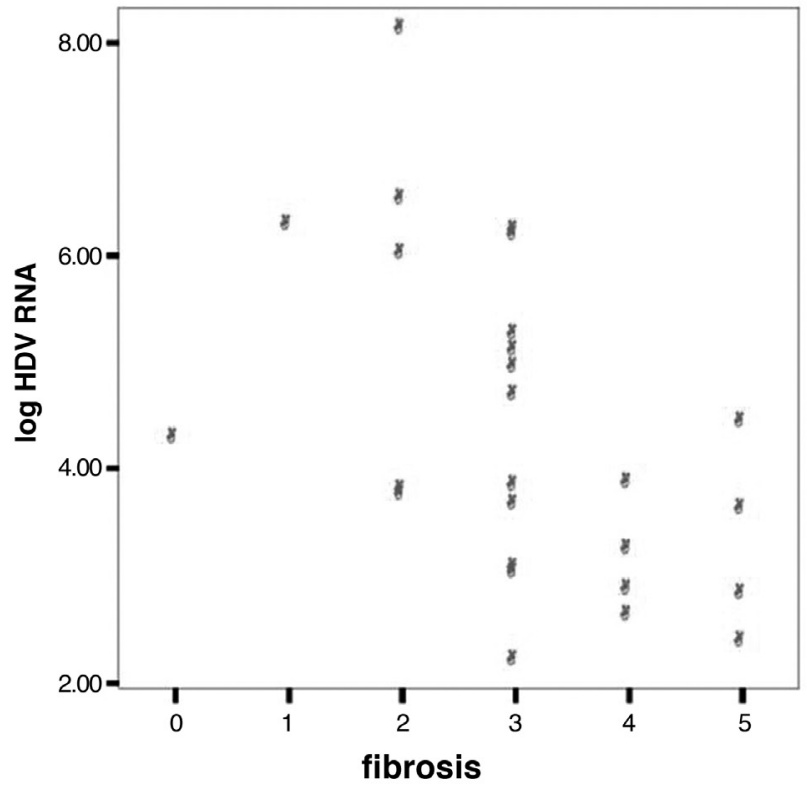

Figure 1. Relation between Log hepatitis delta virus RNA and fibrosis stage in chronic delta hepatitis group $(r=0.572, p=0.002)$ HDV: Hepatitis delta virus

Table 3. Results of correlation analysis in the patients with chronic hepatitis B

\begin{tabular}{|l|l|l|}
\hline \multicolumn{2}{|l|}{} & Log HBV DNA \\
\hline ALT & Pearson correlation & $0.417(* *)$, \\
& $p$ & $p<0.001$ \\
& $n$ & 87 \\
\hline AST & Pearson correlation & $0.344\left(^{* *}\right)$, \\
& $p$ & $p<0.01$ \\
& $n$ & 87 \\
\hline NIA & Pearson correlation & 0.139 \\
& $p$ & $p=0.237$ \\
& $n$ & 74 \\
\hline Stage & Pearson correlation & 0.141 \\
& $p$ & $p=0.231$ \\
& $n$ & 74 \\
\hline
\end{tabular}

${ }^{*}$ Correlation is significant at the level of 0.01 (2-tailed), ${ }^{*}$ Correlation is significant at the level of 0.05 (2-tailed)

HBV: Hepatitis B virus, ALT: Alanine aminotransferase, AST: Aspartate aminotransferase, N/A: Not applicable 
$35.06 \pm 9.53$ years, respectively. Cirrhotic patients were older than non-cirrhotic subjects $(p<0.01)$, consistent with previous studies. On the other hand, we have found that the mean age of patients with DA cirrhosis was lower than reported in previous studies. This difference arises from the presence of higher number of new cases among study participants and indicates perinatal transmission of both viruses HBV and HDV. Therefore, it indicates the importance of vaccination against HBV in eradication of delta hepatitis.

Yamashiro et al. (13) reported that there was no statistically significant difference in mean ALT levels between patients with CHD and those with cirrhosis $(130.7 \pm 214.1$ and $84.4 \pm 65.3$, respectively) but asymptomatic patients had significantly lower ALT levels as compared to CHD group $(p<0.05)$ and cirrhosis group $(p<0.05)$. Wu et al. (14) reported higher ALT levels than in our study. In our study, AST level was found to be significantly higher in DA cirrhotic patients as compared to the group with $\mathrm{CHB}$ $(p=0.009)$. We also found that the albumin level was significantly

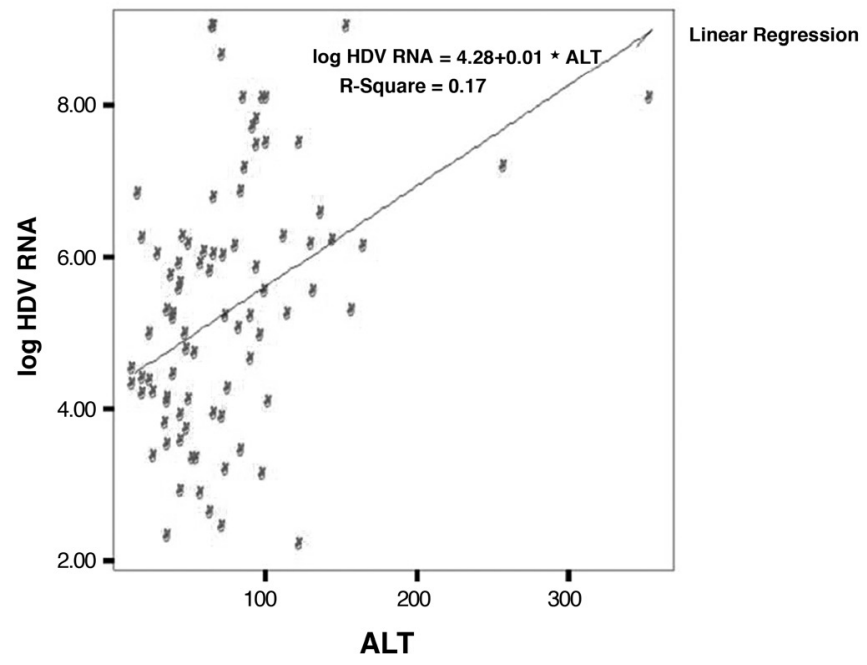

Figure 2. Relation between Log hepatitis B virus DNA and alanine aminotransferase in chronic hepatitis B group

ALT: Alanine aminotransferase, HDV: Hepatitis delta virus

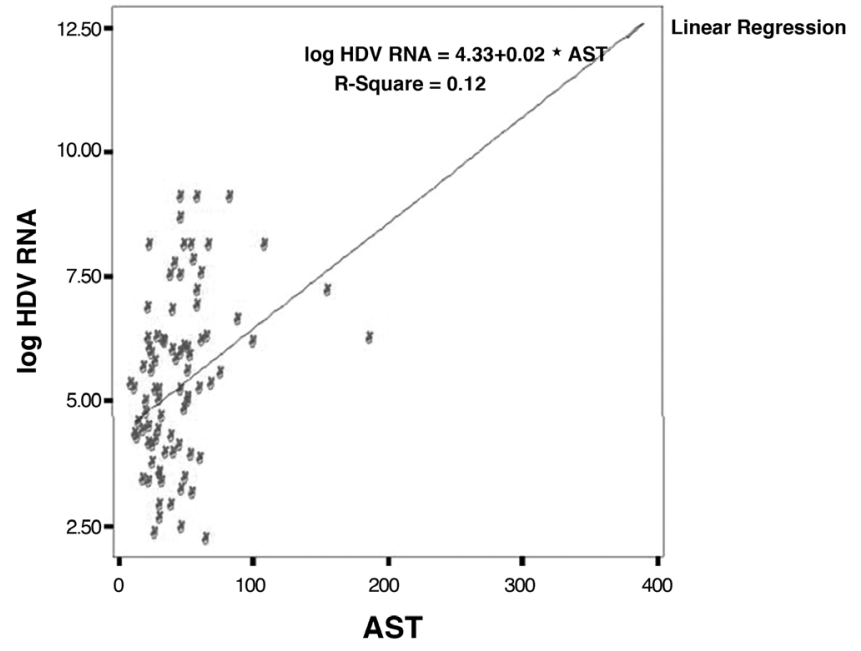

Figure 3. Relation between log hepatitis B virus DNA and aspartate aminotransferase in chronic hepatitis $B$ group

AST: Aspartate aminotransferase, HDV: Hepatitis delta virus lower in DA cirrhosis as compared to non-cirrhotic patients $(p<0.001)$. No significant difference was found between patients with $\mathrm{CHD}$ and $\mathrm{CHB}(\mathrm{p}=0.321)$. This result supports the previous study of Yamashiro et al. (13) because in that study, albumin level was not found to be statistically significantly different between cirrhosis (4.4 \pm 0.8$), \mathrm{CHD}(4.5 \pm 0.5)$ and asymptomatic (4.5 \pm 0.5$)$ patient groups. In the present study, platelet count was found to be significantly lower in cirrhotic patients as compared to that in patients with $\mathrm{CHD}$ and patients with $\mathrm{CHB}$ infection $(\mathrm{p}<0.001$, $\mathrm{p}<0.001$ ). Platelet count was significantly lower in the $\mathrm{CHD}$ as compared to the CHB patients $(p<0.001)$. These results appear to support the results of a similar study existing in the literature (13).

In the present study, there was no statistically significant difference in HBV DNA level between patients of DA cirrhosis (3.42 $\pm 1.05 \log _{10}$ copies/mL) and CHD (3.84 $1.09 \log _{10}$ copies/ $\mathrm{mL})(p=0.466)$. However, HBV DNA levels in DA cirrhosis patients were significantly lower as compared to patients with $\mathrm{CHB}$ $(5.31 \pm 1.70)(p<0.001)$. Likewise, HBV DNA levels in patients with $\mathrm{CHD}$ were found to be significantly lower as compared to that in patients with $\mathrm{CHB}$ infection $(\mathrm{p}<0.001)$. HDV RNA level was not significantly different between patients with DA cirrhosis and patients with CHD ( $p=0.335)$. Yamashiro et al. (13) found no difference between the patient groups (asymptomatic, chronic hepatitis and cirrhosis) in terms of HBV DNA levels. Wu et al. (14) found that HDV RNA level was the highest in patients with acute hepatitis $(98 \%)$, whereas it was found at decreasing concentrations $(74 \%, 74 \%, 63 \%)$ in patients with chronic hepatitis, cirrhosis and hepatocellular carcinoma, respectively $(p=0.002)$. HBV DNA level was the lowest in patients with acute hepatitis $(61 \%)$ as compared to the other groups $(66 \%, 70 \%, 80 \%)(p=0.002)$, and consequently, they concluded that HDV was more dominant in the progression of disease (14). The results of our study revealed that HBV DNA levels were not statistically different between DA cirrhosis patients and patients with CHD. This result is similar to the result of the study conducted by Yamashiro et al. (13). However, HBV DNA levels in both groups were significantly lower than that in patients with chronic HBV infection. This outcome indicates not only suppressive character of HDV on HBV, but also supports the hypothesis that delta hepatitis is the primary agent responsible for progression of the disease (14).

In the present study, a correlation was found between serum HDV RNA and fibrosis stage. The findings indicated that HDV RNA positively correlated with necroinflammatory activity as well. It was also revealed that HDV RNA positively correlated with ALT level in CHD patients. In a study conducted by Braga et al. (15), mean HDV-RNA showed positive correlation with inflammatory activity and fibrosis stage. HDV viral load was correlated positively with serum levels of liver enzymes and inversely with platelet count. HBV viral load showed no correlation with any of the above-mentioned parameters. As a consequence, HDV may possibly play an important and direct role in the development of necroinflammatory activity and fibrosis. The results of our study confirm the findings in the study conducted by Braga et al. (15).

Higher necroinflammation score and advanced stage of fibrosis and accordingly more severe disease were observed in patients with $\mathrm{CHD}(9.30 \pm 2.89)$ than in patients with $\mathrm{CHB}(5.95 \pm 2.82)$ $(p=0.001)$. In a study from Turkey conducted by Albayrak et al. (16), 
12 patients with $\mathrm{CHD}$ underwent biopsy and the mean fibrosis stage was found to be $1.91 \pm 1.22$ and mean necroinflammation score was found to be $8.92 \pm 1.83$. While necroinflammation score was similar with that in our study, fibrosis stage was lower than in our study.

\section{Conclusion}

Our study revealed that age of onset of hepatitis and, accordingly, age of onset of related liver cirrhosis are lower in Turkey. ALT levels are not different between patients with $\mathrm{CHD}$, DA cirrhosis and $\mathrm{CHB}$. HBV DNA appears to be suppressed in patients with delta hepatitis as compared to patients with $\mathrm{CHB}$. Histologically more severe findings were observed in patients with $\mathrm{CHD}$ and in HDV-positive cirrhotic patients. These results support the hypothesis that delta hepatitis together with hepatitis B plays a role as the dominant factor and accelerates disease progression.

\section{Ethics}

Ethics Committee Approval: Retrospective study.

Informed Consent: Retrospective study.

Peer-review: Externally peer-reviewed.

\section{Authorship Contributions}

Surgical and Medical Practices: K.Y., Concept: M.S.Y., K.Y., Design: M.S.Y., K.Y., Data Collection or Processing: M.S.Y., Analysis or Interpretation: M.S.Y., K.Y., Literature Search: M.S.Y., K.Y., Writing: M.S.Y.

Conflict of Interest: No conflict of interest was declared by the authors.

Financial Disclosure: The authors declared that this study received no financial support.

\section{References}

1. Wedemeyer H, Manns MP. Epidemiology, pathogenesis and management of hepatitis D: update and challenges ahead. Nat Rev Gastroenterol Hepatol. 2009;7:31-40.

2. Hughes SA, Wedemeyer H, Harrison PM. Hepatitis delta virus. Lancet. 2011;378:73-85.

3. Rizzetto M, Ciancio A. Epidemiology of hepatitis D. Semin Liver Dis. 2012;32:211-219.
4. Farci P. Delta hepatitis: an update. J Hepatol. 2003;39(Suppl 1):212-219.

5. Rizzetto M. Hepatitis D: thirty years after. J Hepatol. 2009;50:10431050.

6. Stroffolini T, Almasio PL, Sagnelli E, Mele A, Gaeta GB; Italian Hospitals' Collaborating Group. Evolving clinical landscape of chronic hepatitis B: A multicenter Italian study. J Med Virol. 2009;81:1999-2006

7. Değertekin H, Yalçin K, Yakut M, Yurdaydin C. Seropositivity for delta hepatitis in patients with chronic hepatitis B and liver cirrhosis in Turkey: a meta-analysis. Liver Int. 2008;28:494-498.

8. Le Gal F, Badur S, Hawajri NA, Akyüz F, Kaymakoglu S, Brichler S, Zoulim F, Gordien E, Gault E, Dény P. Current hepatitis delta virus type 1 (HDV1) infections in central and eastern Turkey indicate a wide genetic diversity that is probably linked to different HDV1 origins. Arch Virol. 2012;157:647-659.

9. Bahcecioglu IH, Aygun C, Gozel N, Poyrazoglu OK, Bulut Y, Yalniz $M$. Prevalence of hepatitis delta virus (HDV) infection in chronic hepatitis B patients in eastern Turkey: still a serious problem to consider. J Viral Hepat. 2011;18:518-524.

10. Ishak K, Baptista A, Bianchi L, Callea F, De Groote J, Gudat F, Denk $\mathrm{H}$, Desmet V, Korb G, MacSween RN, et al. Histological grading and staging of chronic hepatitis. J Hepatol. 1995;22:696-699.

11. Standish RA, Cholongitas E, Dhillon A, Burroughs AK, Dhillon AP. An appraisal of the histopathological assessment of liver fibrosis. Gut. 2006:55:569-578.

12. Fiel MI. Pathology of chronic hepatitis B and chronic hepatitis C. Clin Liver Dis. 2010;14:555-575.

13. Yamashiro $T$, Nagayama $K$, Enomoto $N$, Watanabe $H$, Miyagi $T$, Nakasone H, Sakugawa H, Watanabe M. Quantitation of the level of hepatitis delta virus RNA in serum, by real-time polymerase chain reaction--and its possible correlation with the clinical stage of liver disease. J Infect Dis. 2004;189:1151-1157.

14. Wu JC, Chen TZ, Huang YS, Yen FS, Ting LT, Sheng WY, Tsay SH, Lee SD. Natural history of hepatitis D viral superinfection: significance of viremia detected by polymerase chain reaction. Gastroenterology. 1995;108:796-802.

15. Braga WS, de Oliveira CM, de Araújo JR, Castilho Mda C, Rocha JM, Gimaque JB, Silva ML, Vasconcelos HL, Ramasawmy R, Paraná R. Chronic HDV/HBV co-infection: predictors of disease stage---a case series of HDV-3 patients. J Hepatol. 2014;61:12051211.

16. Albayrak A, Coşkun M, Uyanıkoğlu A, Bayır Y, Yılmaz H, Kibar YI, Tay A, Albayrak F. The Evaluation of Pegylated Interferon Therapy in Patients with Chronic Hepatitis Delta. Viral Hepat J. 2012;18:6870. 